\title{
Mortality and Severity of COVID-19 Patients with Chronic Obstructive Pulmonary Disease: A Meta-Analysis
}

\author{
Atika Mima Amalin'), Setyo Sri Rahardjo²), Hanung Prasetya3) \\ 1)Masters Program in Public Health, Universitas Sebelas Maret \\ 2)Faculty of Medicine, Universitas Sebelas Maret \\ ${ }^{3)}$ Health Polytechnics, Ministry of Health Surakarta
}

\section{ABSTRACT}

Background: COVID-19 has become a pandemic in all countries including Indonesia. The death rate from COVID-19 is concentrated in elderly patients and those with comorbidities. COPD is one of the comorbidities that can worsen and even cause death. COPD ranks in the top 3 leading causes of death in the world causing 2.3 million deaths in 2019. This study aims to analyze the effect of COPD comorbidities on mortality and severity of COVID-19 patients.

Subjects and Method: This study used a systematic review and meta-analysis by following the PRISMA flow chart. Search articles through journal databases, namely: Google scholar, PubMed, Science Direct and Link Springer. The articles search was done by considering the eligibility criteria defined in the PICO model. $\mathrm{P}=$ COVID-19 patient; $\mathrm{I}=\mathrm{COPD}$ participant; $\mathrm{C}=$ without $\mathrm{COPD}$; $\mathrm{O}=$ need for mechanical ventilation, ICU admission, and death. Inclusion criteria were cohort full paper articles, in English, multivariate analysis with adjusted Odds Ratio. Articles analyzed with RevMan 5.3.

Results: The 13 cohort study designs reviewed with a meta-analysis to estimate the risk of death showed that comorbid COPD increased the risk of death $(\mathrm{aOR}=1.33 ; 95 \% \mathrm{CI}=1.08$ to $1.64 ; \mathrm{p}=$ 0.007). 9 cohort study designs were reviewed with a meta-analysis to estimate the risk of severity with indicators of mechanical ventilation need $(\mathrm{aOR}=1.38 ; 95 \% \mathrm{CI}=1.05$ to $1.82 ; \mathrm{p}=0.020) .7$ cohort study designs were reviewed by meta-analysis to estimate the risk of severity with indicators of risk of ICU admission ( $\mathrm{aOR}=1.25 ; 95 \% \mathrm{CI}=1.04$ to $1.50 ; \mathrm{p}=0.020)$.

Conclusion: COPD comorbidities increase the risk of need for mechanical ventilation, ICU admission and death among COVID-19 patients.

Keywords: COVID-19, COPD, death, severity

\section{Correspondence:}

Atika Mima Amalin. Masters Program of Public Health, Universitas Sebelas Maret. Jl. Ir. Sutami 36A, Surakarta 57126, Central Java. Email: atikamima125@gmail.com. Mobile:085767052088.

\section{Cite this as:}

Amalin AM, Rahardjo SR, Prasetya H (2021). Mortality and Severity of COVID-19 Patients with Chronic Obstructive Pulmonary Disease: A Meta-Analysis. J Epidemiol and Public Health. 06(03): 333-346. https://doi.org/10.26911/jepublichealth.2021.06.03.07.

\section{BACKGROUND}

In December 2019, the SARS-CoV2 or COVID-19 virus first appeared in China, precisely in Wuhan. COVID-19 is still a pandemic in Indonesia and even throughout the world. The number of positive confirmed cases of COVID-19 in September 242021 were 230,418,451 cases according to reported data (WHO, 2021).

Chronic Obstructive Pulmonary Disease or COPD is a non-communicable disease in which airflow obstruction occurs 
in the respiratory tract caused by lung inflammation (Ministry of Health, 2008). COPD is in the top 3 diseases that cause death in the world causing 2.3 million deaths in 2019 (WHO, 2019).

Death in COVID-19 patients has a much higher prevalence if the patient has comorbidities, patients with comorbid COPD have a prevalence of $10.6 \%$ ( $\mathrm{Hu}$ et al., 2020). Other studies have also found that COPD comorbidities can exacerbate COVID-19 disease and even increase the risk of death (Graziani et al., 2020; Hernández-Galdamez et al., 2020; Purroy and Arque, 2021).

COPD increases the risk of poor clinical outcomes due to poor lung function (Lee et al., 2021). The obstruction of air flow in the respiratory tract results in a lack of oxygen in the body, resulting in alveolar damage and changes in respiratory physiology (Asyrofy et al., 2021). Patients with COPD have a high prevalence of coronary ischemia and other risk factors that may worsen the COVID-19 prognosis (Graziani et al., 2020).

There were many primary research that have conducted studies on the association of COPD comorbidities with the risk of death and severity of COVID-19 patients, further analysis is needed to obtain more convincing conclusions. Researchers are interested in conducting a meta-analysis on "Mortality and Severity of COVID-19 Patients with Concomitant Chronic Obstructive Pulmonary Disease".

\section{SUBJECTS AND METHOD}

\section{Study Design}

This study used a systematic review and meta-analysis of primary articles with a cohort study design comparing comorbid COPD with no COPD on the risk of death and outcome of COVID-19 patients. This study followed the PRISMA flow diagram.
Search articles through journal databases, namely: Google scholar, PubMed, Science Direct and Link Springer. Article search was done by considering the eligibility criteria defined in the PICO model. $\mathrm{P}=$ COVID-19 patient; $\mathrm{I}=$ COPD participant; $\mathrm{C}=$ without $\mathrm{COPD} ; \mathrm{O}=$ need for mechanical ventilation. ICU admission and death. The keywords used are: "COPD" OR "Comorbidity" AND "COVID-19" OR "Corona virus" AND "Mortality" OR "poor outcome”.

\section{Inclusion Criteria}

The articles included in the inclusion criteria are: 1) Full text articles with a cohort study design and in English; 2) Outcome articles on risk of death and severity (need for mechanical ventilation and ICU admission); 3) Analysis of multivariate adjusted Odds Ratio (aOR) data.

\section{Exclusion Criteria}

Articles that are not included in the criteria for analysis are: 1) Articles with bivariate odds ratio analysis; 2) the relationship measure used aHR/ARR: 3) the reported outcome is not death or COVID-19 severity.

\section{Definition of Operational Variable}

Mortality: is death in patients with confirmed COVID-19 who are categorized as alive or dead. The instrument is a death certificate for a COVID-19 patient.

Severity: is a worsening condition of patients with COVID-19 disease characterized by the need for mechanical ventilation and ICU admission. The instrument is the patient's medical record.

COPD: Chronic obstructive pulmonary disease is a disease in which airflow obstruction occurs in the respiratory tract, the obstruction is associated with the presence of inflammation in the lungs due to the presence of harmful and toxic particles or gases. The instrument is the medical record of patients diagnosed with COPD. 


\section{Data Analysis}

The association of COPD comorbidity with mortality and severity of COVID-19 patients was analyzed using the Review Manager (RevMan 5.3). The severity of the COVID19 condition with indicators of the need for mechanical ventilation and ICU admission. Relationship measure adjusted Odds Ratio 95\% CI. Forest plots show the estimated effect of COPD comorbidities on mortality and severity of COVID-19 patients. Heterogeneity in studies is shown by the intuitive index $\left(\mathrm{I}^{2}\right)$. Fixed effect model is used in homogeneous research and random effects is used in heterogeneous research. Funnel plot shows publication bias.

\section{RESULTS}

An electronic database search have found 2,981 articles. After deleting duplicated articles, 2,554 articles were filtered. 370 full text articles were assessed for eligibility. A total of 22 articles that fulfilled the inclusion criteria were synthesized in a quantitative meta-analysis. 10 articles came from the North American continent, 6 from the European continent and 6 articles from the Asian continent. The process of searching for articles with a feasibility assessment is shown in Figure 1. Quality assessment using the Critical Appraisal Skill Program (CASP) for cohort research is shown in table 2.

\section{The effect of COPD on mortality in COVID-19 patients.}

The forest plot in Figure 2 showed that comorbid chronic obstructive pulmonary disease increased the risk of death in COVID-19 patients by 1.33 times and was statistically significant $(\mathrm{aOR}=1.33 ; 95 \%$ $\mathrm{CI}=1.08$ to $1.64 ; \mathrm{p}=0.007)$. The hetero- geneity of the study data showed $\mathrm{I}^{2}=93 \%$ so that the estimation was carried out by using a random effects model approach. Figure 3 funnel plot showed no publication bias seen from the symmetrical distribution of the plot. 5 plots are on the right side, 7 plots are on the left side and 1 plot is in the middle of the line.

\section{The effect of COPD on the need for mechanical ventilation in COVID- 19 patients}

COPD comorbidities increase the severity of COVID-19 as shown in Figures 4 and 6 . Figure 4 showed that COPD comorbidities increase the need for mechanical ventilation in COVID-19 patients by 1.38 times $(\mathrm{aOR}=1.38 ; 95 \% \mathrm{CI}=1.05$ to $1.82 ; \mathrm{p}=$ 0.020). The heterogeneity of the research data showed the score of $\mathrm{I}^{2}=82 \%$ so that the estimation is carried out using a random effects model approach. Figure 5 funnel plot showed no publication bias seen from the symmetrical distribution of the plot. 3 plots are on the right side, 5 plots are on the left side and 1 plot is in the middle of the line.

\section{The effect of COPD on ICU admis- sion in COVID-19 patients}

The forest plot in Figure 6 showed that COPD comorbidities increased the risk of ICU admission for COVID-19 patients by 1.25 times $(\mathrm{aOR}=1.25 ; 95 \% \mathrm{CI}=1.04$ to $1.50 ; p=0.020)$. The heterogeneity of the study data showed the score of $\mathrm{I}^{2}=61 \%$ so that the estimation was carried out using a random effects model approach. The funnel plot in Figure 7 showed that there was no publication bias seen from the symmetrical distribution of the plot. 2 plots are on the right side, 2 plots are on the left side and 3 plots are close to the center line. 


\section{Table 1. Characteristics of the Meta-analysis primary article}

\begin{tabular}{|c|c|c|c|c|c|c|c|c|c|}
\hline \multirow[t]{2}{*}{ No } & \multirow{2}{*}{$\begin{array}{l}\text { Author } \\
\text { (Year) }\end{array}$} & \multirow[t]{2}{*}{ Country } & \multirow[t]{2}{*}{ Study Design } & \multicolumn{2}{|c|}{ Sample } & \multirow{2}{*}{$\begin{array}{c}\mathbf{P} \\
\text { (Population) }\end{array}$} & \multirow{2}{*}{$\begin{array}{c}\text { I } \\
\text { (Intervention) }\end{array}$} & \multirow{2}{*}{$\begin{array}{c}\mathrm{C} \\
\text { (Comparison) }\end{array}$} & \multirow{2}{*}{$\begin{array}{c}\mathrm{O} \\
\text { (Outcome) }\end{array}$} \\
\hline & & & & COVID-19 & COPD & & & & \\
\hline 1 & $\begin{array}{l}\text { Cedano et al } \\
2021\end{array}$ & America & Cohort retrospectivt & 132 & 11 & $\begin{array}{l}\text { Adult patient confirmed } \\
\text { COVID-19 }\end{array}$ & COPD comorbid & No COPD & Death \\
\hline 2 & Choi et al 2020 & Korea & Cohort retrospectivt & 7341 & 678 & COVID-19 confirmed patient & COPD comorbid & No COPD & $\begin{array}{l}\text { Death, Mechanici } \\
\text { Ventilation }\end{array}$ \\
\hline 3 . & $\begin{array}{l}\text { Gerwen et al } \\
2020\end{array}$ & America & Cohort retrospectivt & 3703 & 145 & COVID-19 confirmed patient & COPD comorbid & No COPD & $\begin{array}{l}\text { Death, Mechanici } \\
\text { Ventilation }\end{array}$ \\
\hline 4. & Guan et al 2020 & China & Cohort retrospectiv & 39420 & 636 & COVID-19 confirmed patient & COPD comorbid & No COPD & $\begin{array}{l}\text { Death, Mechanici } \\
\text { Ventilation, ICU }\end{array}$ \\
\hline 5 . & Lee et al 2021 & Korea & Cohort retrospectivt & 7590 & 141 & COVID-19 confirmed patient & COPD comorbid & No COPD & Death \\
\hline 6. & Meza et al 2021 & America & Cohort retrospectivt & ( 387008 & 7449 & $\begin{array}{l}\text { Patients aged >35 years ol } \\
\text { confirmed COVID-19 }\end{array}$ & COPD comorbid & No COPD & Death \\
\hline 7 . & Oh et al 2021 & $\begin{array}{l}\text { South } \\
\text { Korea }\end{array}$ & Cohort retrospectivt & 122040 & 4488 & COVID-19 confirmed patient & COPD comorbid & No COPD & Death \\
\hline 8. & Lohia et al 2021 & America & Cohort retrospectiv & 1871 & 317 & $\begin{array}{l}\text { Patients aged }>17 \text { years ol } \\
\text { confirmed COVID-19 }\end{array}$ & COPD comorbid & No COPD & $\begin{array}{l}\text { Death, Mechanici } \\
\text { Ventilation, ICU }\end{array}$ \\
\hline 9 . & $\begin{array}{l}\text { Corradini et al } \\
2021\end{array}$ & Italia & Cohort retrospectivt & 1505 & 156 & $\begin{array}{l}\text { Adult patient confirme } \\
\text { COVID-19 }\end{array}$ & COPD comorbid & No COPD & Death \\
\hline 10. & $\begin{array}{l}\text { Beltramo et al } \\
2021\end{array}$ & France & Cohort retrospectivt & 89530 & 4866 & COVID-19 confirmed patient & COPD comorbid & No COPD & Death, ICU \\
\hline 11. & Chen et al 2020 & China & Cohort retrospectiv & 3309 & 42 & COVID-19 confirmed patient & COPD comorbid & No COPD & Death \\
\hline 12. & $\begin{array}{l}\text { Gude-Sampredo } \\
\text { et al } 2020\end{array}$ & Spain & $\begin{array}{l}\text { Cohort } \\
\text { retrospective }\end{array}$ & 10454 & 180 & COVID-19 confirmed patient & COPD comorbid & No COPD & Death \\
\hline 13. & $\begin{array}{l}\text { Carbonell et al } \\
2021\end{array}$ & Spain & $\begin{array}{l}\text { Cohort } \\
\text { retrospective }\end{array}$ & 3795 & 269 & COVID-19 confirmed patient & COPD comorbid & No COPD & Death \\
\hline 14 & $\begin{array}{l}\text { Angelidi et al } \\
2021\end{array}$ & America & $\begin{array}{l}\text { Cohort } \\
\text { retrospective }\end{array}$ & 144 & 22 & $\begin{array}{l}\text { Adult patient confirmed } \\
\text { COVID-19 }\end{array}$ & COPD comorbid & No COPD & $\begin{array}{l}\text { Mechanical } \\
\text { Ventilation }\end{array}$ \\
\hline 15 & Raad et al 2021 & America & $\begin{array}{l}\text { Cohort } \\
\text { retrospective }\end{array}$ & 1020 & 105 & $\begin{array}{l}\text { Patients aged }>17 \text { years old } \\
\text { confirmed COVID-19 }\end{array}$ & COPD comorbid & No COPD & $\begin{array}{l}\text { Mechanical } \\
\text { Ventilation }\end{array}$ \\
\hline 16. & Fried et al 2020 & America & $\begin{array}{l}\text { Cohort } \\
\text { retrospective }\end{array}$ & 11721 & 1737 & COVID-19 confirmed patient & COPD comorbid & No COPD & $\begin{array}{l}\text { Mechanical } \\
\text { Ventilation }\end{array}$ \\
\hline 17 & Hobbs et al 2021 & America & $\begin{array}{l}\text { Cohort } \\
\text { retrospective }\end{array}$ & 502 & 33 & $\begin{array}{l}\text { Adult patient confirmed } \\
\text { COVID-19 }\end{array}$ & COPD comorbid & No COPD & $\begin{array}{l}\text { Mechanical } \\
\text { Ventilation }\end{array}$ \\
\hline 18. & Wu et al 2020 & China & $\begin{array}{l}\text { Cohort } \\
\text { retrospective }\end{array}$ & 1048 & 50 & COVID-19 confirmed patient & COPD comorbid & No COPD & $\begin{array}{l}\text { Mechanical } \\
\text { Ventilation }\end{array}$ \\
\hline
\end{tabular}




\begin{tabular}{|c|c|c|c|c|c|c|c|c|c|}
\hline \multirow[t]{2}{*}{ No } & \multirow{2}{*}{$\begin{array}{l}\text { Author } \\
\text { (Year) }\end{array}$} & \multirow[t]{2}{*}{ Country } & \multirow[t]{2}{*}{ Study Design } & \multicolumn{2}{|c|}{ Sample } & \multirow{2}{*}{$\begin{array}{c}\mathbf{P} \\
\text { (Population) }\end{array}$} & \multirow{2}{*}{$\begin{array}{c}\text { I } \\
\text { (Intervention) }\end{array}$} & \multirow{2}{*}{$\begin{array}{c}\mathrm{C} \\
\text { (Comparison) }\end{array}$} & \multirow{2}{*}{$\begin{array}{c}\text { O } \\
\text { (Outcome) }\end{array}$} \\
\hline & & & & COVID-19 & COPD & & & & \\
\hline 29 & Garcia et al 2021 & Mexico & $\begin{array}{l}\text { Cohort } \\
\text { retrospective }\end{array}$ & 13842 & 359 & COVID-19 confirmed patient & COPD comorbid & No COPD & ICU \\
\hline 20 & $\begin{array}{l}\text { Santorelli et al } \\
2021\end{array}$ & England & $\begin{array}{l}\text { Cohort } \\
\text { retrospective }\end{array}$ & 582 & 78 & COVID-19 confirmed patient & COPD comorbid & No COPD & ICU \\
\hline 21 & $\begin{array}{l}\text { Timberlake et al } \\
2021\end{array}$ & America & $\begin{array}{l}\text { Cohort } \\
\text { retrospective }\end{array}$ & 275 & 26 & COVID-19 confirmed patient & COPD comorbid & No COPD & ICU \\
\hline 22 & $\begin{array}{l}\text { Doriane et al } \\
2020\end{array}$ & Belgium & $\begin{array}{l}\text { Cohort } \\
\text { retrospective }\end{array}$ & 596 & 46 & $\begin{array}{l}\text { Adult patient confirmed } \\
\text { COVID-19 }\end{array}$ & COPD comorbid & No COPD & ICU \\
\hline
\end{tabular}

\section{Table 2. CASP quality assessment for cohort studies}

\begin{tabular}{|c|c|c|c|c|c|c|c|c|c|c|c|c|}
\hline No & Question & $\begin{array}{c}\text { Cedano et } \\
\text { al. } 2020\end{array}$ & $\begin{array}{l}\text { Choi } \\
\text { et al. } \\
2020\end{array}$ & $\begin{array}{l}\text { Gerwen } \\
\text { et al. } \\
2020\end{array}$ & $\begin{array}{l}\text { Guan et } \\
\text { al. } 2020\end{array}$ & $\begin{array}{l}\text { Lee } \\
\text { et al. } \\
2021\end{array}$ & $\begin{array}{l}\text { Meza } \\
\text { et al. } \\
2021\end{array}$ & $\begin{array}{l}\text { Oh } \\
\text { et al. } \\
2021\end{array}$ & $\begin{array}{l}\text { Lohia et } \\
\text { al. } 2021\end{array}$ & $\begin{array}{l}\text { Corradi } \\
\text { ni et al. } \\
2021\end{array}$ & $\begin{array}{c}\text { Beltra } \\
\text { mo et a } \\
2021\end{array}$ & $\begin{array}{l}\text { Chen } \\
\text { et al } \\
2020\end{array}$ \\
\hline 1. & Does this study address clearly focused issues & 2 & 1 & 2 & 2 & 2 & 2 & 2 & 2 & 2 & 2 & 2 \\
\hline & $\begin{array}{l}\text { Is the cohort conducted in an acceptable } \\
\text { manner }\end{array}$ & 2 & 2 & 2 & 2 & 2 & 2 & 2 & 2 & 2 & 2 & 2 \\
\hline 3 & $\begin{array}{l}\text { Is the exposure accurately measured to } \\
\text { minimize bias }\end{array}$ & 2 & 2 & 2 & 2 & 2 & 2 & 2 & 2 & 2 & 2 & 2 \\
\hline 4 & $\begin{array}{l}\text { Are the results measured accurately to } \\
\text { minimize bias? }\end{array}$ & 2 & 2 & 2 & 2 & 2 & 2 & 2 & 2 & 2 & 2 & 2 \\
\hline 5 & $\begin{array}{l}\text { Have the authors identified all the important } \\
\text { confounding factors? Have they taken } \\
\text { confounding factors into account in the } \\
\text { design and/or analysis? }\end{array}$ & 2 & 2 & 2 & 2 & 2 & 2 & 2 & 2 & 2 & 2 & 2 \\
\hline 6. & $\begin{array}{l}\text { Is the follow-up subject complete enough? Is } \\
\text { the follow-up of the subject long enough? }\end{array}$ & 2 & 2 & 2 & 2 & 2 & 2 & 2 & 2 & 2 & 2 & 2 \\
\hline 7 & $\begin{array}{l}\text { What is the outcome of this study on } \\
\text { mortality or severity? }\end{array}$ & 2 & 2 & 2 & 2 & 2 & 2 & 2 & 2 & 2 & 2 & 2 \\
\hline & Are the results precise? & 2 & 2 & 2 & 2 & 2 & 2 & 2 & 2 & 2 & 2 & 2 \\
\hline & Do you believe in the results? & 2 & 2 & 2 & 2 & 2 & 2 & 2 & 2 & 2 & 2 & 2 \\
\hline & $\begin{array}{l}\text { Can the results be applied to the local } \\
\text { population? }\end{array}$ & 2 & 2 & 2 & 2 & 2 & 2 & 2 & 2 & 2 & 2 & 2 \\
\hline 11. & Are the results of this study consistent with & 2 & 2 & 2 & 2 & 2 & 2 & 2 & 2 & 2 & 2 & 2 \\
\hline
\end{tabular}




\begin{tabular}{|c|c|c|c|c|c|c|c|c|c|c|c|c|}
\hline 12. & $\begin{array}{l}\text { other available evidence? } \\
\text { What are the implications of this study for } \\
\text { practice? }\end{array}$ & 2 & 2 & 2 & 2 & 2 & 2 & 2 & 2 & 2 & 2 & 2 \\
\hline & Total & 24 & 23 & 24 & 24 & 24 & 24 & 24 & 24 & 24 & 24 & 24 \\
\hline
\end{tabular}

Yes = 2; Cannot Tell $=1 ;$ No $=0$

\section{Table 3. Next}

\begin{tabular}{|c|c|c|c|c|c|c|c|c|c|c|c|c|}
\hline No & Question & $\begin{array}{c}\text { Gude- } \\
\text { Sampredo } \\
\text { et al } 2020 \\
\end{array}$ & $\begin{array}{l}\text { Carbon } \\
\text { el et al } \\
2021\end{array}$ & $\begin{array}{l}\text { Angelidi } \\
\text { et al. } \\
\text { 2021 }\end{array}$ & $\begin{array}{l}\text { Raad et } \\
\text { al } 2021\end{array}$ & $\begin{array}{l}\text { Fried at } \\
\text { al } 2020\end{array}$ & $\begin{array}{c}\text { Hobbs } \\
\text { et al } \\
2021 \\
\end{array}$ & $\begin{array}{c}\text { Wu } \\
\text { et al } \\
2020\end{array}$ & $\begin{array}{c}\text { Garcia } \\
\text { et al } \\
2021 \\
\end{array}$ & $\begin{array}{c}\text { Santoreli et } \\
\text { al } \\
\mathbf{2 0 2 1} \\
\end{array}$ & $\begin{array}{c}\text { Timber- } \\
\text { lake et al } \\
2021 \\
\end{array}$ & $\begin{array}{l}\text { Doriane et } \\
\text { al } 2020\end{array}$ \\
\hline 1. & $\begin{array}{l}\text { Does this study address clearly focused } \\
\text { issues }\end{array}$ & 2 & 2 & 2 & 1 & 2 & 1 & 2 & 2 & 2 & 2 & 2 \\
\hline 2. & $\begin{array}{l}\text { Is the cohort conducted in an } \\
\text { acceptable manner }\end{array}$ & 2 & 2 & 2 & 2 & 2 & 2 & 2 & 2 & 2 & 2 & 2 \\
\hline 3 & $\begin{array}{l}\text { Is the exposure accurately measured to } \\
\text { minimize bias }\end{array}$ & 2 & 2 & 2 & 2 & 2 & 2 & 2 & 2 & 2 & 2 & 2 \\
\hline 4. & $\begin{array}{l}\text { Are the results measured accurately to } \\
\text { minimize bias? }\end{array}$ & 2 & 2 & 2 & 2 & 2 & 2 & 2 & 2 & 2 & 2 & 2 \\
\hline 5. & $\begin{array}{l}\text { Have the authors identified all the } \\
\text { important confounding factors? Have } \\
\text { they taken confounding factors into } \\
\text { account in the design and/or analysis? }\end{array}$ & 2 & 2 & 2 & 2 & 2 & 2 & 2 & 2 & 2 & 2 & 2 \\
\hline 6. & $\begin{array}{l}\text { Is the follow-up subject complete } \\
\text { enough? Is the follow-up of the subject } \\
\text { long enough? }\end{array}$ & 2 & 2 & 2 & 2 & 2 & 2 & 2 & 2 & 2 & 2 & 2 \\
\hline 7. & $\begin{array}{l}\text { What is the outcome of this study on } \\
\text { mortality or severity? }\end{array}$ & 2 & 2 & 2 & 2 & 2 & 2 & 2 & 2 & 2 & 2 & 2 \\
\hline 8. & Are the results precise? & 2 & 2 & 2 & 2 & 2 & 2 & 2 & 2 & 2 & 2 & 2 \\
\hline 9. & Do you believe in the results? & 2 & 2 & 2 & 2 & 2 & 2 & 2 & 2 & 2 & 2 & 2 \\
\hline 10. & $\begin{array}{l}\text { Can the results be applied to the local } \\
\text { population? }\end{array}$ & 2 & 2 & 2 & 2 & 2 & 2 & 2 & 2 & 2 & 2 & 2 \\
\hline 11. & $\begin{array}{l}\text { Are the results of this study consistent } \\
\text { with other available evidence? }\end{array}$ & 2 & 2 & 2 & 2 & 2 & 2 & 2 & 2 & 2 & 2 & 2 \\
\hline 12. & $\begin{array}{l}\text { What are the implications of this study } \\
\text { for practice? }\end{array}$ & 2 & 2 & 2 & 2 & 2 & 2 & 2 & 2 & 2 & 2 & 2 \\
\hline & Total & 24 & 24 & 24 & 23 & 24 & 23 & 24 & 24 & 24 & 24 & 24 \\
\hline
\end{tabular}

Yes = 2; Cannot Tell $=1 ;$ No $=0$ 
Amalin et al./ Mortality and Severity of COVID-19 Patients with COPD

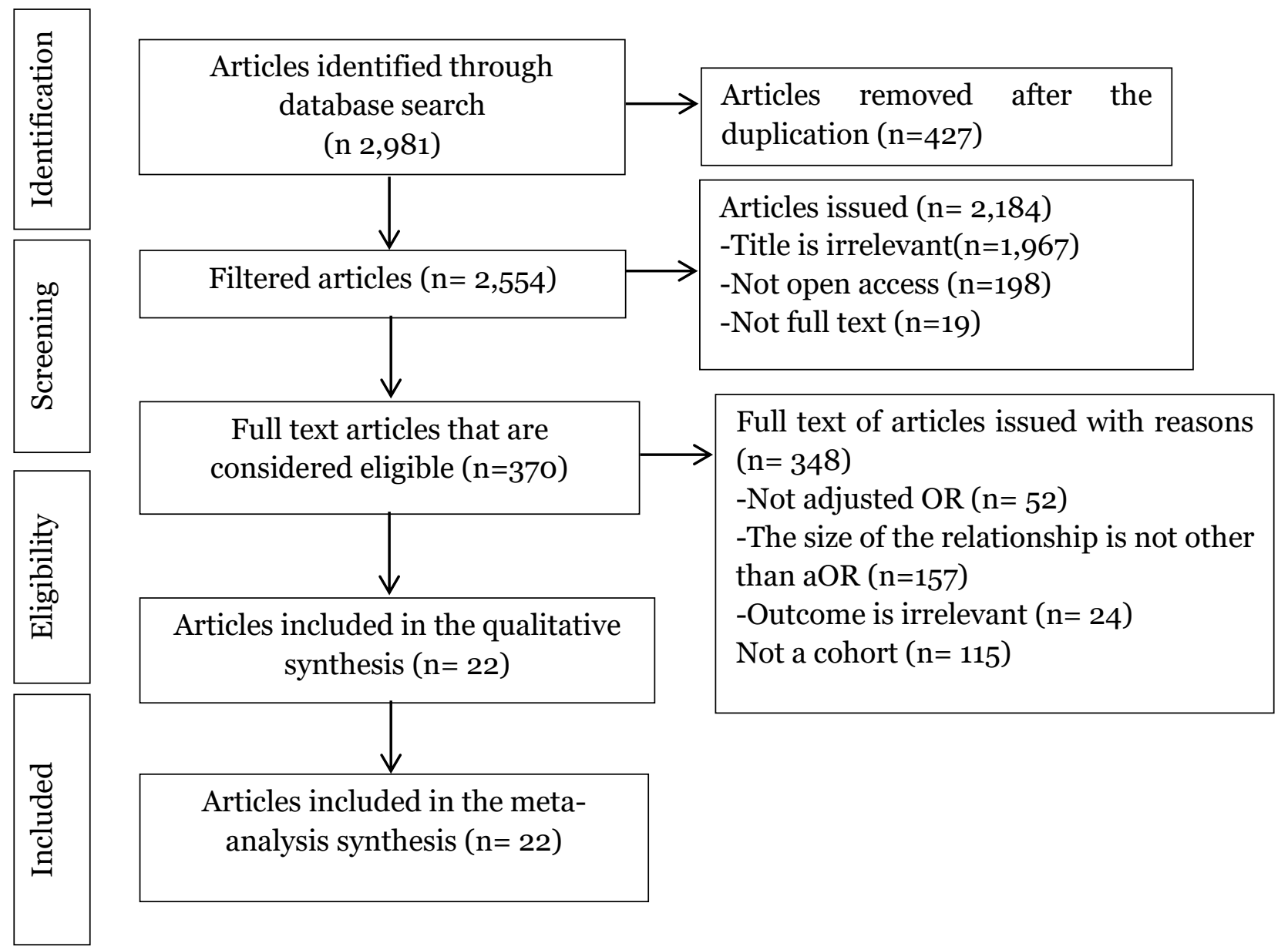

Figure 1. PRISMA Flowchart

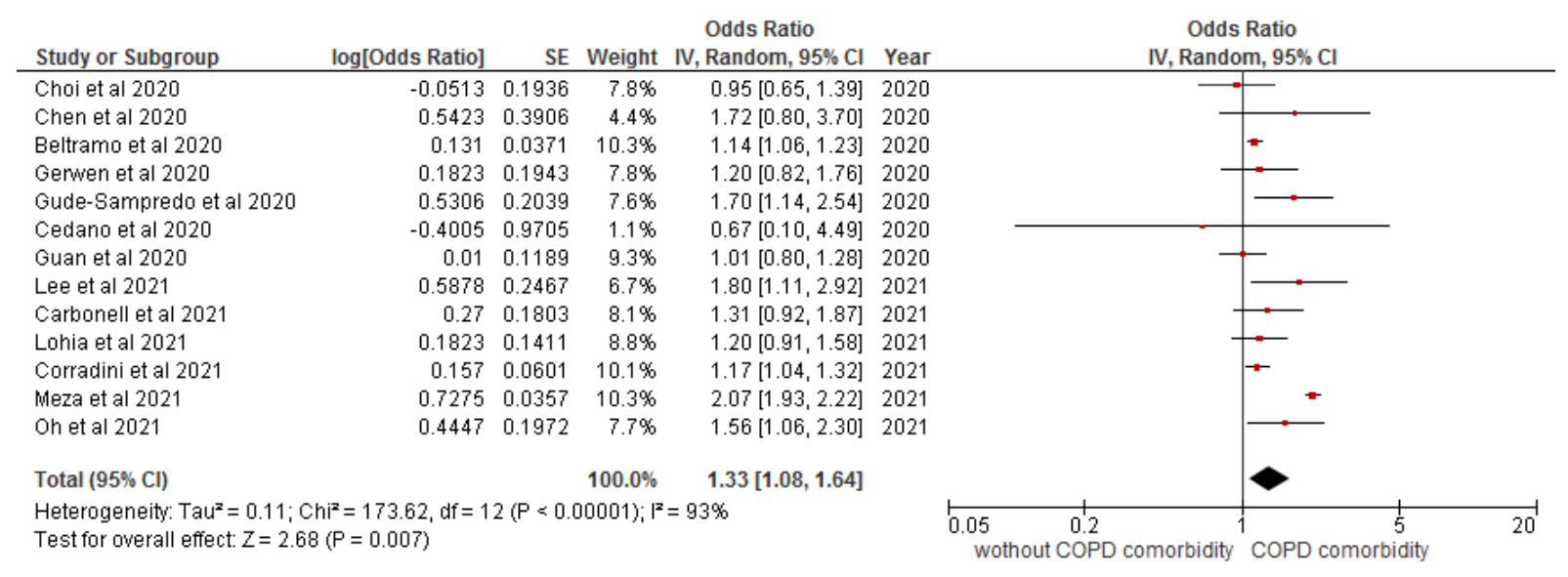

Figure 2. Forest plot of the relationship between COPD
comorbidity with the death risk of COVID-19 patient 
Amalin et al./ Mortality and Severity of COVID-19 Patients with COPD

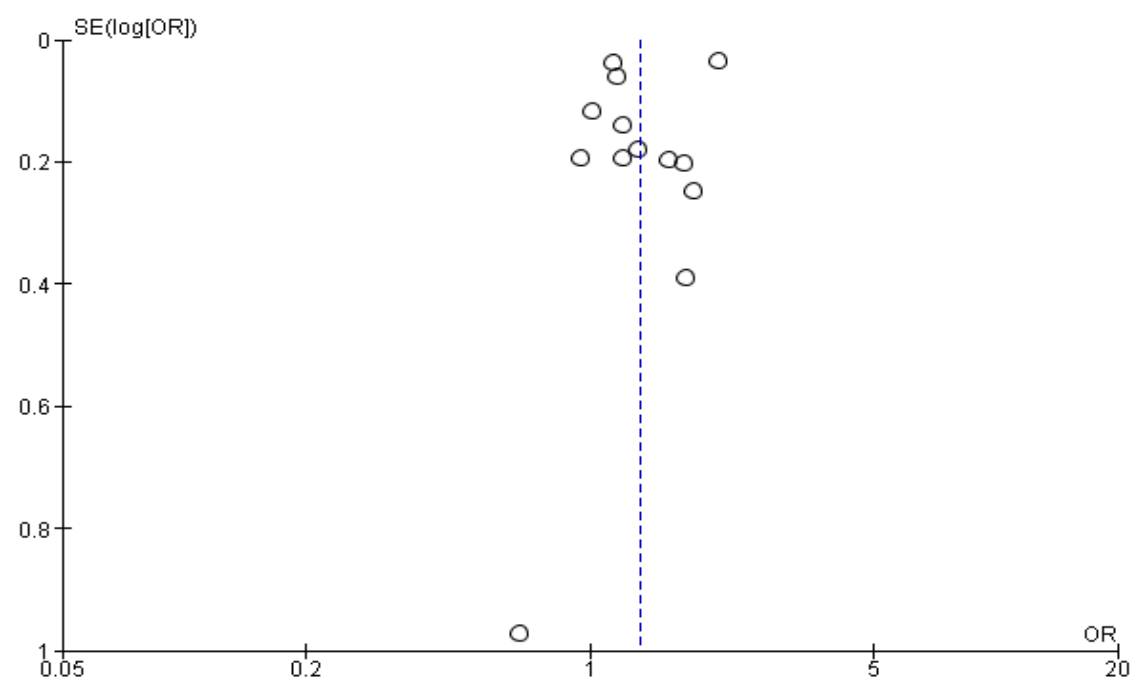

Figure 3. Funnel Plot of the relationship between COPD comorbidity with the death risk of COVID-19 patient

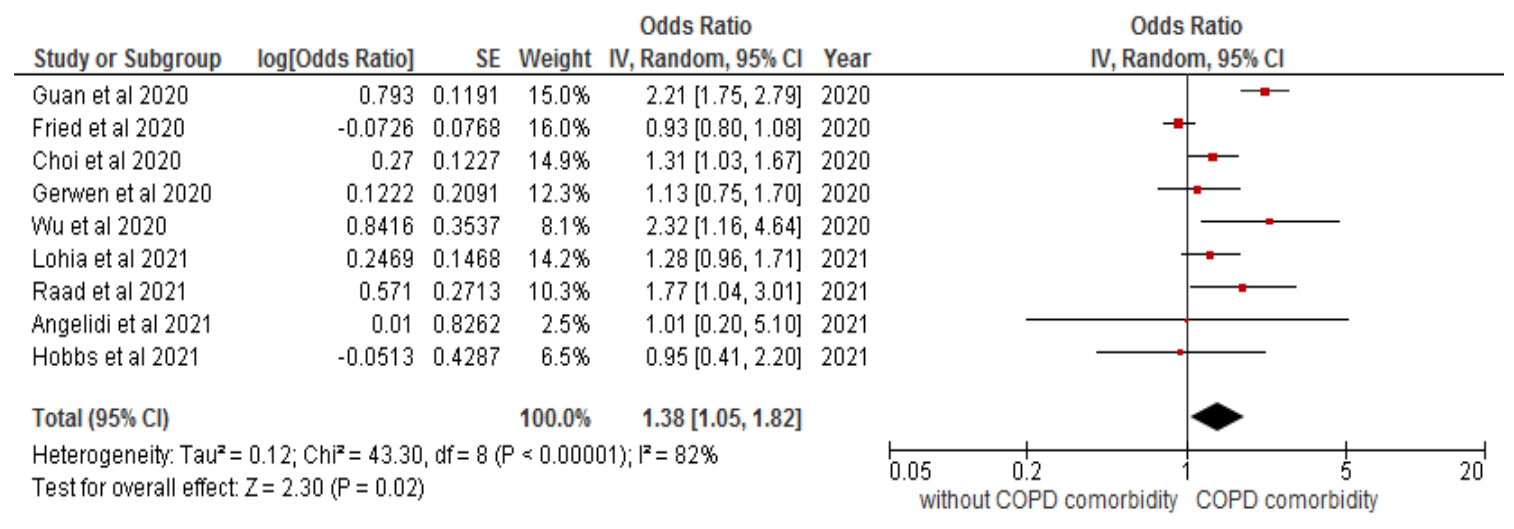

Figure 4. Forest plot of COPD comorbidity relationship with mechanical ventilation needs of COVID-19 patients

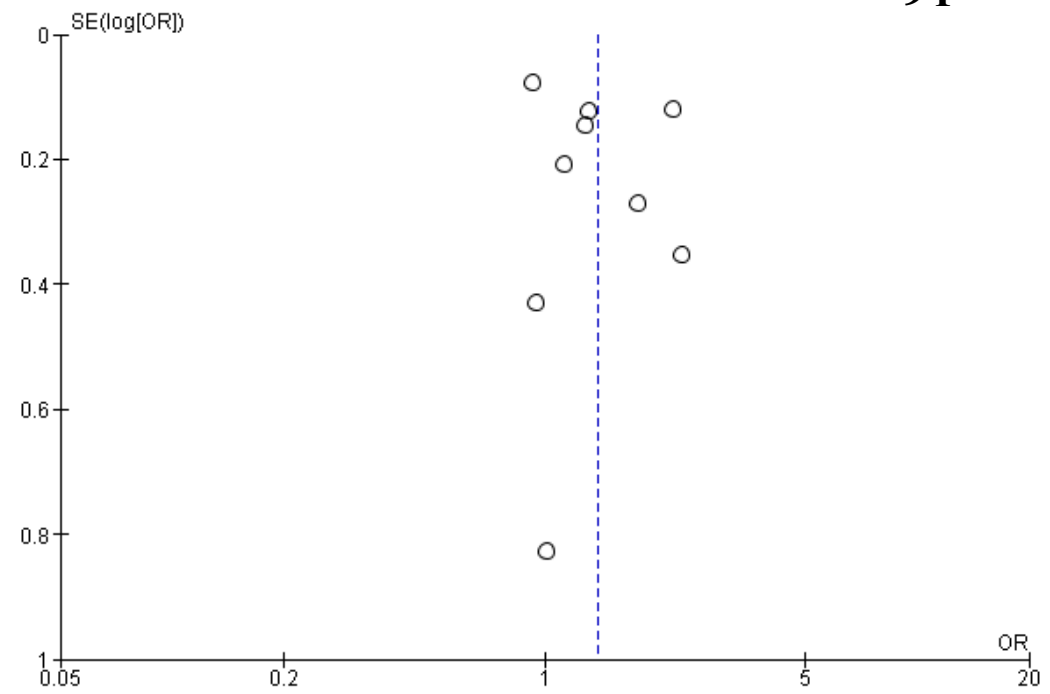

Figure 5. Funnel Plot of COPD comorbidity relationship with mechanical ventilation needs of COVID-19 patients 
Amalin et al./ Mortality and Severity of COVID-19 Patients with COPD

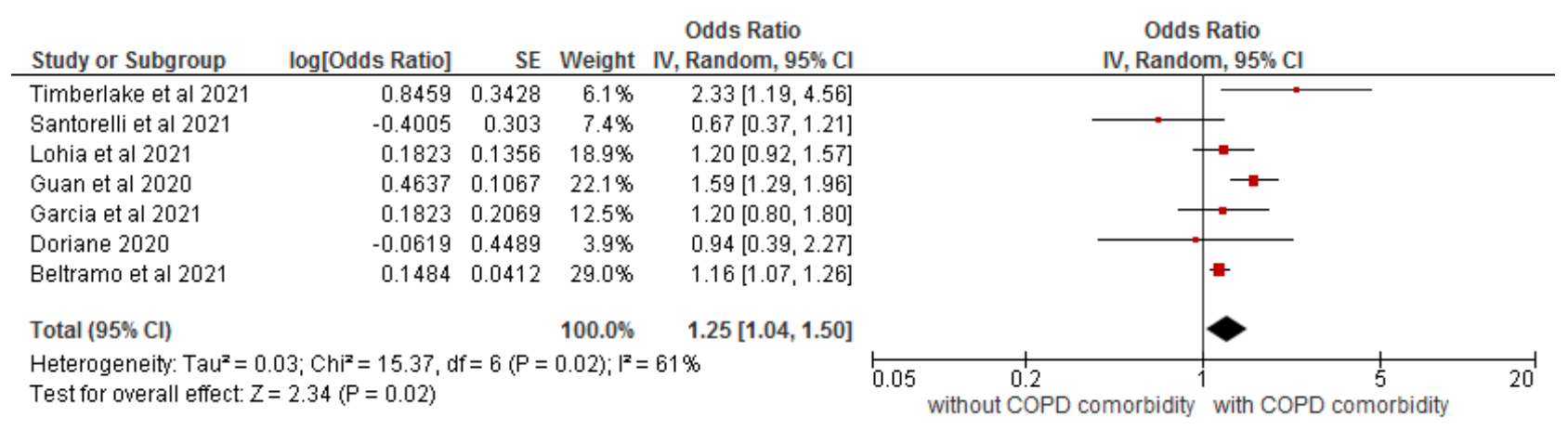

Figure 6. Forest plot of the relationship between COPD comorbidities with the risk of entering the ICU for COVID-19 patients

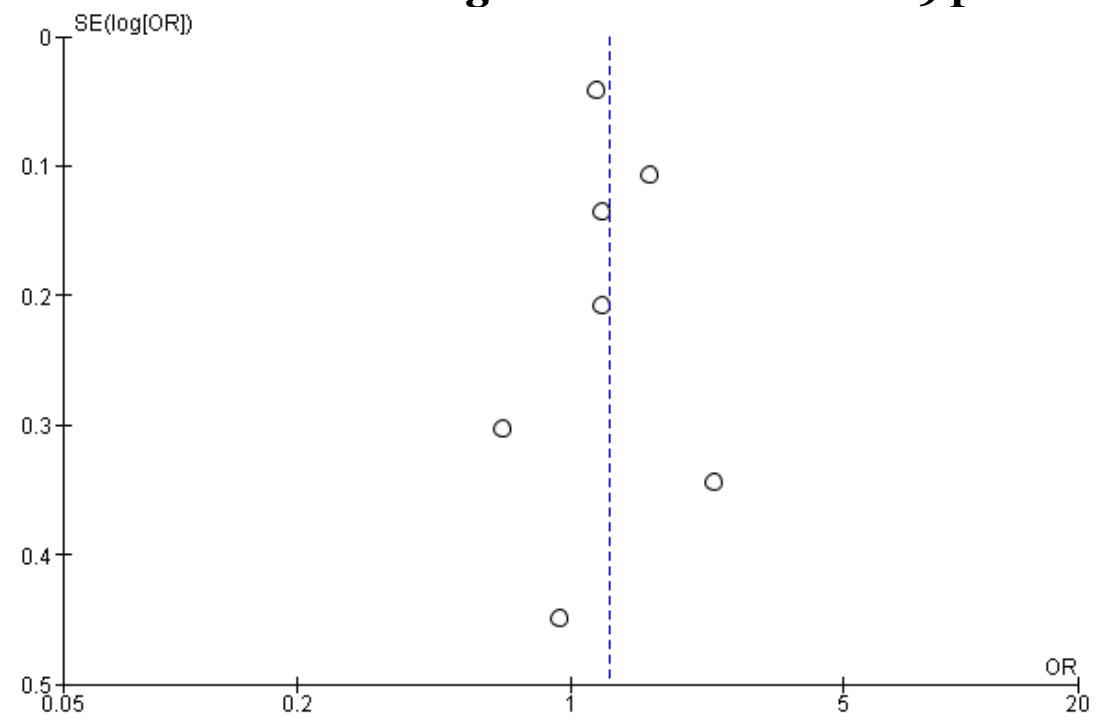

Figure 7. Funnel plot of the relationship between COPD comorbidities with the risk of ICU admission for COVID-19 patients

\section{DISCUSSION}

This systematic review study and metaanalysis estimated the association of comorbid COPD in COVID-19 patients with the risk of death and the severity of the patient's condition. The severity of the condition is seen from 2 indicators, namely the need for mechanical ventilation and ICU admission.

\section{COPD increases the risk of death in COVID-19 patients}

The results of the forest plot of the association of COPD comorbidity with the risk of death from COVID-19 in Figure 2 show that COPD comorbidity increased the risk of death and it was statistically significant
$(\mathrm{aOR}=1.33 ; 95 \% \mathrm{CI}=1.08$ to $1.64 ; \mathrm{p}=$ 0.007).

These results are similar to Meza et al (2021) who conducted a study on the risk of death in COVID-19 patients with COPD comorbidities. The study conducted by Meza showed that COPD comorbidities had a high risk of death $(\mathrm{aOR}=2.07 ; 95 \% \mathrm{CI}=$ 1.93 to 2.22 ; $p<0.001$ ).

COPD patients in the respiratory tract epithelium secrete inflammatory cytokines and chemokines, such as leukotriene B4 (LTB4), interleukin-6 (IL-6), IL-8 (CXCL8) and tumor necrosis factor- $\alpha$ (TNF- $\alpha$ ), and other mediators in lungs (Fauzia, 2016). An excessive increase in cytokines will result in a cytokine storm, patients infected with 
severe SARS-CoV-2 show a cytokine storm that continues to develop into ARDS (Rosyanti and Hadi, 2020).

\section{COPD increases the risk of mecha- nical ventilation needs}

The forest plot of the relationship between COPD comorbidities and the need for mechanical ventilation of COVID-19 patients in Figure 4 showed that COPD comorbidities increased the need for mechanical ventilation and it was statistically significant $(\mathrm{aOR}=1.38 ; 95 \% \mathrm{CI}=1.05$ to $1.82 ; \mathrm{p}=$ $0.020)$.

Lohia et al. (2021) conducted a study on mortality, mechanical ventilation requirements and ICU admission in COVID-19 patients with COPD comorbid. COPD comorbidities increased the risk of mechanical ventilation needs $(\mathrm{aOR}=1.28 ; 95 \%$ $\mathrm{CI}=0.96$ to $1.69 ; \mathrm{p}=0.090)$ and increased the risk of $\mathrm{ICU}$ admission $(\mathrm{aOR}=1.20$; 95\% $\mathrm{CI}=0.92$ to $1.58 ; \mathrm{p}=0.180$ ).

Patients with COPD have an increase in neutrophils. In the case of COVID-19, the number of neutrophils has also increased, therefore, patients with severe SARS-CoV-2 infection are often characterized by neutrophilia (Rosyanti and Hadi, 2020). Neutrophils and macrophages will release protease enzymes. Oxidative stress in COPD will affect the balance between proteolytic and anti-proteolytic by activating proteases and inactivating antiproteinases. An imbalance of protease-antiprotease enzymes caused by an increase in neutrophils causes ARDS. Proteases and oxidants will cause extensive lung tissue damage, especially in the part required for gas exchange (Amin, 2016).

3. COPD increases risk of ICU admission for COVID-19 patients

The Forest plot of the association between COPD comorbidities and the risk of ICU admission for COVID-19 patients in Figure 6 showed that COPD comorbidity increased the risk of ICU admission and was statis- tically significant $(\mathrm{aOR}=1.25 ; 95 \% \mathrm{CI}=1.04$ to $1.50 ; \mathrm{p}=0.020$ ).

These results are similar to a study conducted by Timberlake et al (2021) who conducted a study on the risk of ICU admission in COVID-19 patients with COPD. The study showed that COPD increased the risk of $\mathrm{ICU}$ admission $(\mathrm{aOR}=2.33 ; 95 \% \mathrm{CI}=1.19$ to 4.56$) ; p=0.010$ ).

COPD patients will experience an increase in the ACE-2 enzyme, the SARS $\mathrm{CoV} 2$ virus makes this ACE-2 enzyme as its receptor which then enters the epithelial cells. It causes infection of adjacent cells and the spread of the virus to other organ systems resulting in clinical manifestations which then exacerbates COVID-19 disease (Sin, 2020).

There are several limitations in this study, the first is language bias, because in this study the articles used in the statistical analysis used articles in English only, thus ignoring similar articles in languages other than English. Second, most of the articles in this meta-analysis study are from the North American continent, a small part from the Asian continent and the European continent. This allows for differences in the risk of comorbid COPD with mortality and COVID-19 severity in the continents of Australia, South America and Africa.

In conclusion, COPD comorbidity may be a strong risk factor for the need of mechanical ventilation, ICU admission, and mortality in COVID-19 patients. Future study is expected to use more foreign language articles to minimize language bias. Using subgroup analysis calculations to obtain more accurate evidence of the association of COPD comorbidities with COVID-19 mortality and severity. Health workers and health promoters can take this study into consideration in developing early prevention and determining treatment strategies that can reduce the severity and 
mortality rate in COVID-19 patients with COPD comorbidities.

\section{AUTHORS CONTRIBUTION}

Atika Mima Amalin is the main researcher who determined the title of study, searched and collected the data. Setyo Sri Rahardjo and Hanung Prasetya analyzed the data and reviewed study articles.

\section{CONFLICT OF INTEREST}

There was no conflict of interest in this study.

\section{FUNDING AND SPONSORSHIP}

Personal fund.

\section{ACKNOWLEDGEMENT}

We are really thankful to the Masters Program in Public Health Sciences of Universitas Sebelas Maret, which has supported the publication of this manuscript. The contents of this script are the responsibility of the author.

\section{REFERENCES}

Amin M (2016). Omeostasis sebagai mekanisme perlindungan terhadap kerusakan jaringan paru perspektif dan implikasi teori protease-antiprotease (Homeostasis as a protection mechanism for pulmonary tissue damage perspectives and implications of protease-antiprotease theory). Surabaya: Airlangga University Press. http://repository.unair.ac.id/id/eprint/30411

Angelidi AM, Belanger MJ, Lorinsky MK, Karamanis D, Chamorro-Pareja N, Ognibene J, Palaiodimos l, et al. (2021). Vitamin D status is associated with in-hospital mortality and mechanical ventilation: A cohort of COVID-19 hospitalized patients.
Mayo Clin Proc. 96(4): 875-886. doi: 10.1016/j.mayocp.2021.01.001

Asyrofy A, Arisdiani T, Aspian M (2021). Karakteristik dan kualitas hidup pasien Penyakit Paru Obstruksi Kronik (PPOK) (Characteristics and Quality of Life Patients with Chronic Obstruction Pulmonary Disease (COPD)). Nurscope. 7(1): 13-21.

Beltramo G, Cottenet J, Mariet A, Georges M, Piroth L, Tubbert-Bitter P, Bonniaud $\mathrm{P}$, et al. (2021). Chronic respiratory diseases are predictors of severe outcome in COVID-19 hospitalised patients: a nationwide study. Eur Respir J. doi: 10.1183/13993003.04474-2020).

Budiman A, Majid A, Syam I, Efendi S (2021). gambaran kualitas tidur dan fungsi kognitif pada pasien ppok di BBKPM Makassar (Description of sleep quality and cognitive function in COPD patients at BBKPM Makassar). Jurnal Kesehatan. 14(1): 29. doi: 10.24252/kesehatan.v14i1.14140.

Carbonell L, Urgeles S, Rodriguez A, Bodi M, Martin-Loeches I, Sole-Violan J, Diaz E, et al. (2021). Mortality comparison between the first and second/third waves among 3,795 critical COVID-19 patients with pneumonia admitted to the ICU: A multicentre retrospective cohort study. Elsevier. doi: 10.1016/j.lanepe.2021.100243.

Cedano J, Corona EF, Gonzales-Lara M, Santana M, Younes I, Ayad S, Kossack A, et al. (2021). Characteristics and outcomes of patients with COVID-19 in an intensive care unit of a community hospital; retrospective cohort study. J Community Hosp Intern Med Perspect. 11(1): 27-31. doi: $10.1080 / 20009666.2020 .1830-$ 516. 
Chen J, Bai H, Liu J, Chen G, Liao Q, Yang $\mathrm{J}, \mathrm{Wu} \mathrm{P}$, et al. (2020). Distinct clinical characteristics and risk factors for mortality in female inpatients with coronavirus disease 2019 (COVID19): A Sex-stratified, Large-scale Cohort Study in Wuhan, China. Clin Infect Dis. 3188-3195. doi: 10.1093/cid/ciaa920.

Choi JC, Jung S, Yoon UA, You S, Kim M, Baek MS, Jung J, et al. (2020) Inhaled Corticosteroids and COVID19 Risk and Mortality: A Nationwide Cohort Study. (2020). J. Clin. Med. doi: 10.3390/jcm9113406.

Corradini E, Ventura P, Ageno W, Cogliate CB, Mmuiesan ML, Girelli D, Pirisi $\mathrm{M}$, et al. (2021). Clinical factors associated with death in 3044 COVID-19 patients managed in internal medicine wards in Italy: results from the SIMI-COVID-19 study of the Italian Society of Internal Medicine (SIMI). Intern Emerg Med. doi: 10.1007/s11739-021-02742-8.

Doriane C, Shoppie G, Nathalie M, AnneNoelle F, Marie T, Olivier B, Julien B, et al. (2020). Asthma and COPD are not risk factors for ICU stay and death in case of SARS-CoV-2 infection. Elsevier. doi: 10.1016/j.jaip.2020.09.044

Fauzia D (2017). peranan statin dalam memperbaiki fungsi paru pada penyakit paru obstruktif kronik (PPOK) (The role of statins in improving lung function in chronic obstructive pulmonary disease (COPD)). Jurnal Ilmu Kedokteran. 10(2): 71. doi: 10.26891/jik.v10i2.2016.71-79.

Fried MW, Crawford JM, Mospan AR, Watkins SE, Munoz B, Zink RC, Elliott S, et al. (2021). Patient characteristics and outcomes of 11721 patients with coronavirus disease 2019 (COVID-19) Hospitalized Across the United States. Clin Infect Dis. doi: 10.1093/cid/ciaa1268.

Kammar-Garcia A, Vidal-Mayo JDJ, VraZertuche JM, Lazcano-Hernandez M, Vera-Lopez O, Segura-Badilla O, Aguilar-Alonso P, Navaro-Cruz AR (2021). Impact of comorbidities in Mexican SARS-CoV-2-positive patients: a retrospective analysis in a national cohort. Revista de Investigación Clínica. doi: 10.24875/ric.20000207.

Gerwen MV, Alsen M, Little C, Barlow J, Genden E, Naymagon L, Tremblay D (2020). Risk factors and outcomes of COVID-19 in New York City; a retrospektif cohort study. J Med Virol. doi: 10.1002/jmv.26337.

Graziani D, Sariono JB, Rio-Bermudez CD, Morena D, Diaz T, Castillo M, Alonso $\mathrm{M}$, et al. (2020). Characteristics and prognosis of COVID-19 in Patients with COPD. J. Clin. Med. 9(10): 3259. doi: 10.3390/jcm9103259.

Guan W, Liang W, Shi Y, Gan L, Wang HB, He J, Zhoung N (2021). Chronic respiratory diseases and the outcomes of COVID-19: A Nationwide Retrospective Cohort. Study of 39,420 Cases. J Allergy Clin Immunol Pract. doi: 10.1016/j.jaip.2021.02.041.

Gude-Sampedro F, Fernandez-Merino C, Ferreiro L, Lado-Baleato O, Espasandin-Dominguez J, et al. (2020). 2019 (COVID-19): A sex-stratified, largescale cohort study in Wuhan, China. 1-11. doi: 10.1093/ije/dyaa209.

Hernández-Galdamez DR, Gonzalez-Block MA, Romo-Duenas DK, Lima-Morales R, Hernández-Vicente IA, Lumbreras-Guzman M, Mendez-Hemandez $P$ (2020). Increased risk of hospitalization and death in patients with 
COVID-19 and pre-existing noncommunicable diseases and modifiable risk factors in Mexico. Elshevier Inc. 51(7): 683-689. doi: 10.1016/j.arcmed.2020.07.003.

Hobbs ALV, Turner N, Omer I, Walker MK, Beaulieu RM, Sheikh M, Spires SS, et al. (2020). Risk factors for mortality and progression to severe covid-19 disease in the Southeast United States (US): A report from the SEUS study group. Infect Control Hosp Epidemiol. doi: 10.1017/ice.2020.1435.

$\mathrm{Hu}$ W, Dong M, Xiong M, Zhao D, Zhao Y, Wang M, Tao W, et al. (2020). Clinical courses and outcomes of patients with chronic obstructive pulmonary disease during the covid-19 epidemic in Hubei, China. Int J Chron Obstruct Pulmon Dis. 15: 2237-2248. doi: 10.2147/COPD.S265004.

Lee SC, Son KJ, Han CH, Park SC, Jung JY. (2021). Impact of COPD on COVID19 prognosis: A nationwide population-based study in South Korea. Sci Rep. 11(1): 1-8. doi: 10.1038/s41598021-83226-9.

Lohia P, Sreeram K, Nguyen P, Choudhary A, Kicher S, Yarandi H, Kapur S, Badr MS (2021). Preexisting respiratory diseases and clinical outcomes in COVID-19: a multihospital cohort study on predominantly African American population. Repis Res. 2237. doi: 10.1186/s12931-021-01647-6.

Meza D, Khuder B, Bailey JI, Rosenberg SR, Kalhan R, Reyfman PA (2021). Mortality from COVID-19 in Patients with COPD: A US Study in the $\mathrm{N}_{3} \mathrm{C}$ Data Enclave. Int J Chron Obstruct Pulmon Dis. 16: 2323-2326. doi: 10.2147/COPD.S3180oo.

Oh KT, Song IA (2021). Impact of coronavirus disease-2019 on chronic respiratory disease in South Korea: an NHIS COVID-19 database cohort study. BMC Pulm Med. 21(12). doi: 10.1186/s12890-020-01387-1.

Purroy F, Gloria A (2021). Influence of thromboembolic events in the prognosis of COVID-19 hospitalized patients. Results from a cross sectional study. PLoS One. 16(6): 1-11. doi: 10.1371/journal.pone.0252351.

Raad M, Gorgis S, Abshire C, Yost M, Dabbagh FM, Chehab O, Aurora L, et al. (2021). COVID-19 risk index (CRI): a simple and validated emergency department risk score that predicts mortality and the need for mechanical ventilation. J. Thromb. Thrombolysis. doi: 10.1007/s11239021-02565-6.

Santorelli G, McCooe M, Sheldon TA, Wright J, Lawton T (2021). Ethnicity, pre-existing comorbidities, and outcomes of hospitalised patients with COVID-19. Wellcome Open Res. doi: 10.12688/wellcomeopenres.16580.2.

Sin DD (2020). COVID-19 in COPD: A growing concern. EClinicalMedicine. 26: 100546. doi: 10.1016/j.eclinm.2020.100546.

Timberlake DT, Narayanan D, Ogbogu PU, Raveendran R, Porter K, Scherzer R, Prince B, Greyson MH (2021). Severity of COVID-19 in hospitalized patients with and without atopic disease. World Allergy Organ J. doi: doi.org/10.1016/j.waojou.2021.100508.

WHO (2021). WHO Coronavirus (COVID19) Dashboard. Retrieved from https: //covid19.who.int/ at 9 September 2021.

WHO (2019). Newsroom: Chronic obstructive pulmonary disease (COPD). Retrieved from https://www.who.int/news-room/fact-sheets/detail/chro- 
Amalin et al./ Mortality and Severity of COVID-19 Patients with COPD

nic-obstructive-pulmonary-disease(copd). Pada 2 September 2021

Wu F, Zhou Y, Wang Z, Xie M, Shi Z, Tang $\mathrm{Z}$, Li X, et al. (2020). Clinical characteristics of COVID-19 infection in chronic obstructive pulmonary disease: a multicenter, retrospective, observational study. J Thorac Dis. 12(5): 1811-1823. doi: $10.21037 /$ jtd20-1914. 